International Political Science Association (IPSA)

Terms expiring 1991:

Philip E. Converse, University of Michigan

Robert G. Gilpin, Princeton University

Robert Scalapino, University of California, Berkeley

Social Science Research Council (SSRC)

Term expiring June 30, 1992:

Suzanne Berger, Massachusetts Institute of Technology

\section{A Report on the Congressional Fellowship Program, 1988-89 and 1989-90}

The Congressional Fellowship Program is a professional level internship that gives academics, journalists, federal executives, and other professionals an opportunity to work on the staffs of senators, representatives, and congressional committees. Its goals are:

- to improve the quality of scholarship and teaching on Congress and American national politics;

- to enhance public understanding of Congress and policymaking; and

- to provide professionals from several fields with practical experience in Congress and insight into the legislative process.

Since 1953, the first year of the Program, there have been a total of 1,352 Fellows, including 222 political' scientists, 180 journalists, 654 federal executives, and 278 medical faculty and others.

Although the first class of Fellows had only six members, in recent years the Program has grown to include between 40 and 50 Fellows each year. The political science and journalism Fellows are selected in nationwide competitions. Political science applicants must have completed their doctorates within the last fifteen years or be near completion, and reporters must have a bachelor's degree and between two and ten years of professional experience in newspaper, magazine, television, or radio reporting. Criteria for selection are quality training, demonstrated competence, maturity and responsibility, relevance of fellowship experience to career goals, and potential for professional advancement.

While the political scientists and journalists remain the core of the program and are supported by the APSA through contributions from corporations and foundations, the majority of each year's class of Fellows participates in the pro- gram through affiliate arrangements, including:

- federal executives (Grades 13-16) supported by agency training funds;

- Asian Fellows supported by the Asia Foundation;

- Health Policy Fellows, including medical faculty, supported by the Robert Wood Johnson Foundation and the W. K. Kellogg Foundation;

- anthropology faculty supported by the American Anthropological Association;

- West German Fellows supported by the German Marshall Fund;

- Carl Albert Fellows supported by the Carl Albert Center at the University of Oklahoma; and

- a French Fellow supported by the Fondation Franco-Americaine in Paris.

Those who have funded political scientists and journalists include the Knight Foundation, the Mary Norris Preyer Fund, the New York Times Foundation and the Poynter Fund.

The Walter and Phyllis Shorenstein Family has provided funding to endow a Fellowship in the name of their daughter, Joan Shorenstein Barone. Joan was a well-known and highly respected producer for CBS News who died in 1985 at a tragically early age. The Joan Shorenstein Barone Fellowship is awarded to a broadcast journalist of special merit, and was given for the first time to a 1986-87 Fellow, Jean Powell, news reporter for KEZI-TV in Eugene, Oregon. The 1987 88 recipient was Jay A. Kohn, Capitol Bureau Chief, Montana Television Network, Helena, Montana. William Lewis Graf, State Capitol Reporter, WISC-TV, Madison, Wisconsin, was the recipient for 1988-89, and Philip L. Ingrassia, Assistant News Director and Legislative Reporter for KDLT-TV in Sioux Falls, South Dakota, is the recipient for 1989-90.

The Poynter Fund contribution is designated to support a promising Fellow in print journalism. William D. Zaferos, political reporter for the Appleton PostCrescent, Appleton, Wisconsin, was named the Poynter Fellow for 1987-88. The first Poynter Fellow was Celia Cohen (1985-86), staff reporter for the Wilmington, Delaware News-Journal. Andrew Pollack, City Hall reporter for The Democrat and Chronicle Newspapers, Rochester, New York, was the 1986-87 recipient. The 1988-89 Poynter Fellow was Kenton Bird, editorial page editor, Idahonian/Palouse Empire Daily News, Moscow, Idaho, and Pullman, Washington. Kristen Huckshorn, reporter for the San Jose Mercury News, California, has been selected to be the 1989 -
90 Poynter Fellow.

The Fellowship Program commences in early November with an orientation period that includes meetings and seminars with members of Congress, congressional staffs, political scientists, journalists, lobbyists, government administrators, and others on a wide range of topics relating to Congress and national politics. During this time Fellows also begin exploring possibilities for assignments in congressional offices. These negotiations are conducted by the Fellows themselves, and their placements are decided by the Fellows and the offices in which they will work. Fellows begin work in House or Senate offices in early December, and serve in their initial assignments for about four and a half months. In April they are encouraged to look for new assignments on the other side of the legislature so that each Fellow has an opportunity to experience both the House and Senate during the Fellowship year. Weekly seminars for the Fellows are held throughout the year to supplement the orientation period, and each Fellow also makes one trip with a Senator or Representative to the member's home state or district to observe constituent work and campaign activities.

Kay Sterling is Administrative Director of the Congressional Fellowship Program. Christopher J. Deering, Associate Professor of Political Science at The George Washington University, has recently joined the program as Director for Academic Planning and Development. An Advisory Committee, whose members are listed below, provides overall policy guidance for the Program.

\section{Congressional Fellowship Program Advisory Committee}

Thomas E. Mann, The Brookings Institution, Chairman

David S. Broder, Washington Post

Honorable Robert Dole, Senate Minority Leader

Honorable Thomas S. Foley, Speaker, U.S. House of Representatives

Honorable Bill Frenzel, U.S. House of Representatives

David R. Gergen, U.S. News \& World Report

James F. Hoge, Jr., New York Daily News

Albert R. Hunt, Wall Street Journal

Wayne Kelley, Congressional Quarterly

Honorable Richard G. Lugar, U.S. Senate

Philip Meyer, University of North Carolina

Norman J. Ornstein, American Enterprise Institute

Leonard Parkinson, Atlantic Research Corp.

Honorable Richardson Preyer, Greensboro, North Carolina 
Honorable David E. Price, U.S. House of Representatives

Cokie Roberts, National Public Radio

Robert Rosenzweig, Association of American Universities

Honorable Paul Simon, U.S. Senate

Barbara Sinclair, University of California, Riverside

Charls E. Walker, Charls E. Walker Associates, Inc.

Eddie Williams, Joint Center for Political Studies

Weekly Speakers and Topics, 1989

Susan J. M. Adams, U.S. Department of Labor, panelist, "What's Ahead Following the Fellowship?"

John Agresto, president, The Madison Center, "The Classics and Modern Trends in Education"

William Connelly, Jr., Washington and Lee University, panelist, "What's Ahead Following the Fellowship?"

Carol G. Cox, president, National Committee for a Responsible Federal Budget, "The National Economic Commission",

C-SPAN, a review of C-SPAN as a tool for teachers and Congress

Jerelyn Eddings, editorial writer, Baltimore Sun, a review of her tour of East African nations as an inquiring journalist

The Honorable Barney Frank (D-MA), U.S. Representative, "The Savings and Loan Crisis"

Christopher H. Foreman, Jr., The American University, "Congressional Oversight and Social Regulation"

Alton Frye, director, Washington Office, Council on Foreign Relations, "Opportunities and Pitfalls in the Early Bush Diplomacy"

Roy H. Ginsberg, Skidmore College, "The European Community in the 1990s: Implications for the United States"

Peter Harkness, editor and publisher, Governing magazine, "The New Federalism: Competitive or Cooperative?"'

Kay Johnson, Children's Defense Fund, "Maternal and Child Health Issues in America Today"

Vincent Johnson and Lane Sunderland, Judicial Fellows, U.S. Supreme Court and Federal Judicial Center, respectively; a briefing following attendance at oral arguments at Supreme Court

Sally Katt, U.S. Department of Agriculture, panelist, "What's Ahead Following the Fellowship?"'

Ellen Malcolm, president, Emily's List; a discussion on the activities of Emily's List and opportunities for Democratic women candidates for public office

Donald Steinberg, U.S. Department of State, panelist, "What's Ahead Follow- ing the Fellowship?"

White House Press Briefing with Marlin

Fitzwater, for Journalism Fellows

1989-90 CONGRESSIONAL

FELLOWSHIP PROGRAM

Selection Committee, 1989-90

Political Scientists and Journalists

Roger Davidson, University of Maryland

Christopher J. Deering, George

Washington University

Ronald Elving, Congressional Quarterly

Susan Hammond, American University

Al Hunt, Wall Street Journal

Carol Matlack, National Journal

Federal Fellows

Frederick Holborn, Johns Hopkins University School of Advanced International Studies

Jean Le Masurier, Department of Health and Human Services

Dana Marshall, Department of State

Barbara Rosenfeld

\section{9-90 CONGRESSIONAL FELLOWS}

\section{Political Science Fellows}

Christopher J. Bailey, Lecturer in Politics, Department of American Studies, University of Keele, England

Paul S. Herrnson, Assistant Professor, Department of Political Science, University of Massachusetts

Janet M. Martin, Assistant Professor, Department of Government and Legal Studies, Bowdoin College

\section{Journalism Fellows}

Kristin Huckshorn, Reporter, San Jose Mercury News, San Jose, California

Philip L. Ingrassia, Assistant News Director and Legislative Reporter, KDLT-TV, Sioux Falls, South Dakota (fourth recipient of annual Joan Shorenstein Barone Congressional Fellowship in Broadcast Journalism)

Lisa A. Pullen, Reporter, The Charlotte Observer, Charlotte, North Carolina

Stephen P. Ward, Reporter/Producer, Michigan Public Radio Network, Lansing, Michigan

\section{Robert Wood Johnson}

Health Policy Fellows

Benjamin Chu, Assistant Professor, Department of Medicine, Kings County Hospital, Brooklyn, New York

Philip H. Goodman, Associate Professor of Medicine, University of Nevada, Veterans Administration Medical Center, Reno, Nevada

Melvin D. Shipp, Associate Professor, School of Optometry/The Medical Center, University of Alabama at Birmingham

Danny Wedding, Professor of Medical
Psychology, Department of Psychiatry, School of Medicine, Marshall University, Huntington, West Virginia

Earnestine Willis, Associate Professor of Clinical Pediatrics, University of Chicago, Woodlawn Maternal and Child Health Center, Chicago, Illinois

Edward T. Wimberley, Director, Department of Social Work, Assistant Professor, Department of Preventive Medicine and Community Health, The University of Texas at Galveston

\section{West German Fellows}

Wolfgang J. M. Drechsler, University Lecturer in American Studies, PhilippsUniversitat Marburg

Peter Muller, Adviser in the Akademisches Auslandsamt of the University of Freiburg

\section{French Fellow}

Emmanuele d'Achon, Economic Desk Officer for North America, French Ministry of Foreign Affairs

\section{Asia Foundation Fellows}

Changsu Kim, Senior Researcher, Policy Planning Directorate, Korea Institute for Defense Analyses (KIDA), Seoul

Raja A. Nazrin, Assistant Secretary, Commonwealth Heads of Government Meeting (CHOGM), Organizing Secretariat, Malaysian Foreign Ministry, Kuala Lumpur

Smita Notosusanto, Lecturer, Department of International Relations, Faculty of Social and Political Sciences, University of Indonesia, Jakarta

Mohammad Ziauddin, Director, Foreign Minister's Office, Ministry of Foreign Affairs, Government of Bangladesh, Dhaka

\section{American Anthropological}

Association Fellows

Lesley Gill, Former Fulbright Research Fellow, Centro del Studio de la Realidad Economica y Social, La Paz, Bolivia

Jo Anne Schneider, Adjunct Assistant Professor, Anthropology Department, Temple University, Philadelphia, Pennsylvania

\section{American Society of}

Allied Health Professions

(Kellogg Health Policy Fellow)

Marcia K. Brand, Special Assistant to the Dean and Coordinator, Career Services Center, College of Allied Health Sciences, Thomas Jefferson University, Philadelphia, Pennsylvania 


\section{Carl Albert Fellow}

Kenneth M. Cosgrove, Ph.D. Candidate/ Teaching Assistant, Department of Political Science, University of Oklahoma

\section{Federal Fellows}

Susan J. Clain, Senior Legislative Specialist, U.S. Department of Health and Human Services

Lyn L. Creswell, Major, Land Use Planning Officer, U.S. Marine Corps, U.S. Department of the Navy

Bernard T. Devaney, Senior Intelligence Operations Specialist, Defense Intelligence Agency

Loren B. Ford, Biological Scientist, Forest Service, U.S. Department of Agriculture

Charles David Gustafson, Supervisory Actuary, Pension Benefit Guaranty Corporation

Marjorie W. Holmes, Branch Manager, Office of Information Resources, Central Intelligence Agency

Bruce E. Kasold, Major, Office of the General Counsel, Office of the Secretary of the Army, U.S. Department of the Army

Janice Dunn Lee, Special Assistant to the Chairman for International and State Programs, U.S. Nuclear Regulatory Commission

Denise M. Leger-Lee, Personnel Management Specialist, Animal and Plant Health Inspection Service, U.S. Department of Agriculture

Aubrey D. McElhaney, Program Analyst, NOAA, U.S. Department of Commerce

Mary C. Rubin, Senior Legislative Analyst, The President's Committee on Employment of People with Disabilities, U.S. Department of Labor

John B. Snowden, Branch Chief, National Security Agency

Michael E. Talbert, Branch Chief, Division of Coal Mine Workers' Compensation, Employment Standards Administration, U.S. Department of Labor

Barry Zalcman, Technical Assistant, U.S. Nuclear Regulatory Commission

\section{Foreign Affairs Fellows}

Sharon L. Basso, Intelligence Officer, Central Intelligence Agency

Janey D. Cole, Country Affairs Officer, Andean Region, Latin America, U.S. Information Agency

Jerry A. De Money, LTC, Battalion Commander, U.S. Department of the Army

David P. Fichtner, Intelligence Officer, Central Intelligence Agency

Bruce N. Gray, Former Chief, Visa Section, American Consulate General, Hong Kong (U.S. Department of State)

Number of Congressional Fellows, 1953-1990

\begin{tabular}{|c|c|c|c|c|c|c|}
\hline Year & $\begin{array}{l}\text { Political } \\
\text { Scientists }\end{array}$ & Journalists & $\begin{array}{l}\text { Total } \\
\text { Federal }\end{array}$ & $\begin{array}{c}\text { Federal/ } \\
\text { Foreign } \\
\text { Affairs }\end{array}$ & Other* & TOTAL \\
\hline $1953-54$ & 5 & 1 & & & & 6 \\
\hline $1954-55$ & 4 & 5 & & & 1 & 10 \\
\hline $1955-56$ & 5 & 5 & & & & 10 \\
\hline $1956-57$ & 4 & 6 & & & 1 & 11 \\
\hline $1957-58$ & 10 & 5 & & & & 15 \\
\hline $1958-59$ & 8 & 6 & & & 3 & 17 \\
\hline $1959-60$ & 8 & 7 & & & 5 & 20 \\
\hline $1960-61$ & 8 & 7 & & & 7 & 22 \\
\hline $1961-62$ & 9 & 5 & 5 & & 4 & 24 \\
\hline $1962-63$ & 7 & 8 & 9 & & 6 & 30 \\
\hline $1963-64$ & 8 & 7 & 7 & & 6 & 28 \\
\hline $1964-65$ & 8 & 7 & 11 & & 3 & 29 \\
\hline $1965-66$ & 7 & 6 & 17 & & 9 & 39 \\
\hline $1966-67$ & 5 & 7 & 22 & & 7 & 41 \\
\hline $1967-68$ & 10 & 6 & 23 & & 7 & 46 \\
\hline $1968-69$ & 7 & 9 & 24 & & 7 & 47 \\
\hline $1969-70$ & 11 & 5 & 24 & & 5 & 45 \\
\hline 1970-71 & 8 & 8 & 18 & & 5 & 39 \\
\hline $1971-72$ & 8 & 8 & 27 & $20 / 7$ & 5 & 48 \\
\hline $1972-73$ & 8 & 5 & 26 & $17 / 10$ & 4 & 44 \\
\hline $1973-74$ & 6 & 7 & 26 & $16 / 10$ & 3 & 42 \\
\hline $1974-75$ & 7 & 5 & 27 & $16 / 11$ & 10 & 49 \\
\hline $1975-76$ & 7 & & 27 & $17 / 10$ & 9 & 43 \\
\hline $1976-77$ & 5 & 3 & 28 & $17 / 11$ & 10 & 46 \\
\hline $1977-78$ & 6 & 2 & 27 & $18 / 9$ & 12 & 47 \\
\hline $1978-79$ & 4 & 4 & 28 & $17 / 11$ & 10 & 46 \\
\hline $1979-80$ & 3 & 2 & 30 & $19 / 11$ & 9 & 44 \\
\hline $1980-81$ & 2 & 4 & 21 & $11 / 10$ & 12 & 39 \\
\hline $1981-82$ & 4 & 4 & 28 & $17 / 11$ & 14 & 50 \\
\hline $1982-83$ & 3 & 3 & 27 & $15 / 12$ & 14 & 47 \\
\hline $1983-84$ & 5 & 2 & 27 & $15 / 12$ & 13 & 47 \\
\hline $1984-85$ & 4 & 3 & 26 & $14 / 12$ & 15 & 48 \\
\hline $1985-86$ & 4 & 2 & 25 & $15 / 10$ & 16 & 47 \\
\hline $1986-87$ & 4 & 4 & 23 & $12 / 11$ & 14 & 45 \\
\hline $1987-88$ & 3 & 4 & 22 & $10 / 12$ & 19 & 48 \\
\hline $1988-89$ & 3 & 3 & 24 & $13 / 11$ & 14 & 44 \\
\hline $1989-90$ & 3 & 4 & 25 & $14 / 11$ & 17 & 49 \\
\hline
\end{tabular}

*Includes anthropologists, historians, Harkness Fellows, Carl Albert Fellows, West German Fellows, Robert Wood Johnson Health Policy Fellows, French Fellows, Asia Foundation Fellows, a Ford Foundation Fellow (in 1985-86), and American Society of Allied Health Professions Kellogg Policy Fellows.

Leslie Starr Hart, Chief, Division of Cultural Resources, National Park Service, U.S. Department of the Interior

John F. Johnson, Jr., Major, Operations Officer, U.S. Department of the Army

Eric Lief, Special Assistant to the Comptroller, U.S. Department of State

Raymond J. Pardon, Former Regional Labor Officer for Southern Africa, American Consulate General, Johannesburg (U.S. Department of State)

Stephen J. Tomchik, Special Assistant to the Undersecretary of State for Political Affairs, U.S. Department of State

Kaarn Jayne Weaver, Former Chief, Political/Economic Section, American Consulate General, Hong Kong (U.S. Department of State)

\section{Orientation Speakers}

Henry J. Abraham, University of Virginia, "The Supreme Court and Individual Liberties"

Raymond J. Ahearn, Congressional Research Service, "The Role of Congress in Trade Policy Formulation"

Richard A. Baker, Historian of the U.S. Senate, "The Senate of 1989: Would the Constitution's Framers Recognize It?"

Philip Bond, Office of the Assistant Secretary of Defense for Legislative Affairs, "Congress and the Department of Defense"

Terry Dean, Dean and Company, "The Role of the House Rules Committee in the Legislative Process"'

*Christopher J. Deering, George Washington University and APSA, "The 
Assignments of 1988-89 Fellows, First Half

\begin{tabular}{|c|c|}
\hline Fellow & Office Assigned \\
\hline \multicolumn{2}{|l|}{ Senate } \\
\hline Donald C. Baumer & Thomas A. Daschle (D-SD) \\
\hline Kenton Bird & Timothy E. Wirth (D-CO) \\
\hline Randy D. Ferryman & Alan J. Dixon (D-IL) \\
\hline Ann B. Flood & Senate Committee on Finance (Minority Staff) \\
\hline Nancy F. Green & Timothy E. Wirth (D-CO) \\
\hline Vicki J. Huddleston & Jeff Bingaman (D-NM) \\
\hline Barbara E. Langner & Senate Committee on Finance (Majority Staff) \\
\hline Joel S. Levine & Max S. Baucus (D-MT) \\
\hline Joseph A. Lieberman III & Senate Special Committee on Aging \\
\hline Louise Little & Senate Committee on Labor \& Human Resources \\
\hline William B. Loper & John W. Warner (R-VA) \\
\hline Alan L. Moss & Frank R. Lautenberg (D-NJ) \\
\hline Timothy A. Peterson & J. James Exon (D-NE) \\
\hline Daniel R. Popkey & Jeff Bingaman (D-NM) \\
\hline Ralph C. Rosacker & John McCain (R-AZ) \\
\hline Anthony Schwartz & George J. Mitchell (D-ME) \\
\hline Kenneth L. Sichel & Rudy Boschwitz (R-MN) \\
\hline Gary Duane Smith & Kent Conrad (D-MO) \\
\hline Charles F. Turgeon & William S. Cohen (R-ME) \\
\hline \multicolumn{2}{|l|}{ House of Representatives } \\
\hline William J. Andahazy & House Armed Services Committee \\
\hline Thomas J. Bond & Bill Frenzel (R-MN) \\
\hline Marie-Pascale Boutry & Sander M. Levin (D-MI) \\
\hline James P. Callahan & David R. Obey (D-WI) \\
\hline Hans-Joachim Christe & Morris K. Udall (D-AZ) \\
\hline Elizabeth L. Doolittle & Vic Fazio (D-CA) \\
\hline James H. Edgar Jr. & House Armed Services Committee \\
\hline William Lewis Graf & $\begin{array}{l}\text { House Subcommittee on Elections } \\
\text { Al Swift (D-WA) }\end{array}$ \\
\hline Anthony $\mathrm{T}$. Hawkins & Charles B. Rangel (D-NY) \\
\hline Douglas Hengel & Michael A. Andrews (D-TX) \\
\hline Christopher R. Hill & Stephen J. Solarz (D-NY) \\
\hline Reinhard Kowalewsky & Gary Ackerman (D-NY) \\
\hline Liu Linfei & Bob Wise (D-WV) \\
\hline Ardith L. Maney & Sander M. Levin (D-MI) \\
\hline Richard O. Miller & Dick Cheney (R-WY) \\
\hline Rodrigue Mortel & Sander M. Levin (D-MI) \\
\hline L. Marvin Overby & David E. Price (D-NC) \\
\hline Chirachai Punkrasin & Richard T. Schulze (R-PA) \\
\hline David Rutherford & Thomas E. Petri (R-WI) \\
\hline June C. Schaeffer & House Committee on Veterans' Affairs (Majority Staff) \\
\hline Robert A. Strong & Lee H. Hamilton (D-IN) \\
\hline Charles P. Weber & House Committee on Education \& Labor (Minority Staff) \\
\hline Charles J. Wells & Larry Hopkins (R-KY) \\
\hline Howard C. Wiener III & Peter H. Kostmayer (D-PA) \\
\hline
\end{tabular}

Bicameral Congress"

Evelyn Dubrow, International Ladies Garment Workers Union, "Representing the Interests of Labor"

Terry Eastland, National Legal Center for the Public Interest, "Ethics in Public Life"

Alan Ehrenhalt, Governing magazine, "The Pursuit of Office: How American Politics Has Changed"

*Ronald D. Elving, Congressional Quarterly, "Congress on the Threshold of the 1990s: A Journalist's View"

Christopher H. Foreman, Jr., The Brookings Institution, "Congressional Oversight and Social Regulation"

*Paul Furiga, Thomson Newspaper Bureau, "How to Get a Job on the Hill',

David R. Gergen, U.S. News and World
Report, "Presidential Leadership"

Martin B. Gold, Gold and Liebengood, Inc., "Leadership in the Senate"

*Peter Higgins, Central Intelligence Agency, "How to Get a Job on the Hill"'

William H. Hogan, Jr., House Armed Services Committee, "A Bill Travels through Congress"

*Vicki Huddleston, Department of State, "How to Get a Job on the Hill"

Albert R. Hunt, Wall Street Journal, "How Americans View Washington: Congress, the President and the Press"

Randy Huwa, Common Cause, "Citizens Advocacy: Working with the Press"

The Honorable Sidney L. Jones, Assistant Secretary of the Treasury for Economic Policy, "Foreign Investment in the United States"
Charles Kamasaki, National Council of La Raza, "Our Hispanic Population and Civil Rights",

The Honorable Max M. Kampelman, former Ambassador and Head of the U.S. Delegation to the Negotiations on Nuclear and Space Arms in Geneva, "The Outlook for Arms Control"

The Honorable Dennis E. Kloske, Department of Commerce, "Economic Security as an Element of National Security"

*George Kundanis, Office of the Speaker of the House, "Leadership in the House of Representatives"

The Honorable Richard G. Lugar (R-IN), Senate Committee on Foreign Affairs

*Thomas E. Mann, The Brookings Institution, "Congress Under Siege"

Nicholas Masters, House Committee on the Budget, "The Politics of the Congressional Budget Process"

David Mathiasen, General Accounting Office, "Budgeting in the Executive Branch"

The Honorable Abner J. Mikva, U.S. Court of Appeals, District of Columbia Circuit, "The Judicial System and the Balance of Power"

*Richard O. Miller, Department of the Interior, "How to Get a Job on the Hill"

*Candice J. Nelson, The Brookings Institution, "The Money Chase"

Douglas Norell, Office of Representative Byron L. Dorgan, "How to Hire a Congressman"

The Honorable David R. Obey (D-WI), House of Representatives, "The Foreign Aid Budget"

*Robert B. Okun, House Republican Conference, "Developing Policy, Strategy and Leadership in the Republican Party"'

Van Doorn Ooms, House Committee on the Budget, "The Congressional Budget Process"

*Norman J. Ornstein, American Enterprise Institute, "Major Issues and the 101st Congress"

Rudolph G. Penner, The Urban Institute, "Economic Policies and the Budget Deficit"

The Honorable Roger B. Porter, Assistant to the President for Economic and Domestic Policy, "The White House and Domestic Policy: Making Choices"

Douglas Rosenthal, Esquire, Coudert Brothers, "The European Community: Implications for the United States"

Charls E. Walker, Charls E. Walker Associates, "Lobbying for Business Interests"

*Douglas Waller, Newsweek, "Working in Foreign Policy on the Hill"

Ronald Walters, Howard University, "Black Politics and the Democratic Party: Congress, Policy and Politics" 
Assignments of 1988-89 Fellows, Second Half

\begin{tabular}{|c|c|}
\hline Fellow & Office Assigned \\
\hline \multicolumn{2}{|l|}{ Senate } \\
\hline Armin Abdul Rahman & Joint Economic Committee (Minority Side) \\
\hline Donald C. Baumer & Thomas A. Daschle (D-SD) \\
\hline Thomas J. Bond & Paul Simon (D-IL) \\
\hline Marie-Pascale Boutry & Democratic Policy Committee \\
\hline Hans-Joachim Christe & Timothy E. Wirth (D-CO) \\
\hline Elizabeth L. Doolittle & Joseph Lieberman (D-CT) \\
\hline Randy D. Ferryman & Alan J. Dixon (D-IL) \\
\hline Ann B. Flood & Senate Committee on Finance (Minority Staff) \\
\hline Vicki Huddleston & Jeff Bingaman (D-MN) \\
\hline Barbara E. Langner & Senate Committee on Finance (Majority Side) \\
\hline Joel S. Levine & Max S. Baucus (D-MT) \\
\hline Joseph A. Lieberman III & Senate Special Committee on Aging \\
\hline Louise Little & Senate Committee on Labor \& Human Resources \\
\hline William B. Loper & John W. Warner (R-VA) \\
\hline Alan L. Moss & Frank R. Lautenberg (D-NJ) \\
\hline Richard O. Miller & James Exon (D-NE) \\
\hline Daniel R. Opokey & Jeff Bingaman (D-MN) \\
\hline Chirachai Punkrasin & Steve Symms (R-ID) \\
\hline Ralph C. Rosacker & John McCain (R-AZ) \\
\hline David Rutherford & $\begin{array}{l}\text { Jim Jeffords (R-VT) } \\
\text { Subcommittee on Labor }\end{array}$ \\
\hline Kenneth L. Sichel & Rudy Boschwitz (R-MN) \\
\hline Gary D. Smith & Kent Conrad (D-MO) \\
\hline Robert A. Strong & Richard Lugar (R-IN) \\
\hline Charles Turgeon & William Cohen (R-ME) \\
\hline Charles J. Wells & Ted Stevens (R-AK) \\
\hline \multicolumn{2}{|l|}{ House of Representatives } \\
\hline William J. Andahazy & House Armed Services Committee \\
\hline Kenton Bird & Lee Hamilton (D-IN) \\
\hline James P. Callahan & David R. Obey (D-WI) \\
\hline James H. Edgar, Jr. & House Armed Services Committee \\
\hline William L. Graf & $\begin{array}{l}\text { House Subcommittee on Elections } \\
\text { Al Swift (D-WA) }\end{array}$ \\
\hline Nancy Green & Chet Atkins (D-MA) \\
\hline Anthony T. Hawkins & Charles B. Rangel (D-NY) \\
\hline Douglas Hengel & Michael A. Andrews (D-TX) \\
\hline Christopher R. Hill & Stephen J. Solarz (D-NY) \\
\hline Reinhard Kowalewsky & Gary Ackerman (D-NY) \\
\hline Liu Linfei & Bob Wise (D-WV) \\
\hline Ardith L. Maney & $\begin{array}{l}\text { House Subcommittee on Human Resources \& Intergovernmental } \\
\text { Relations }\end{array}$ \\
\hline Rodrigue Mortel & Sander M. Levin (D-MI) \\
\hline L. Marvin Overby & David E. Price (D-NC) \\
\hline Timothy A. Peterson & John Spratt (D-SC) \\
\hline June C. Schaeffer & House Committee on Veterans' Affairs (Majority Side) \\
\hline Anthony Schwartz & $\begin{array}{l}\text { House Committee on Agriculture } \\
\text { Edward R. Madigan (R-IL) }\end{array}$ \\
\hline Charles P. Weber & House Committee on Education and Labor (Minority Side) \\
\hline Kerry Wiener III & Peter Kostmayer (D-PA) \\
\hline
\end{tabular}

\section{Congressional Research Service Legislative Institute}

Rick Beth, Analyst in American National Government, "Floor Procedures in the House of Representatives"

Jeff Griffith, Deputy Assistant Director for Operations, "Automated Information Sources on Capitol Hill"

Tom Miller, Office of Special Programs, "Overview of CRS"

Dan Mulhollan, Assistant Chief, Government Division, "Overview of CRS"

Ilona Nickels, Analyst in American
National Government, "Floor Procedures in the Senate",

Joseph E. Ross, Director, Congressional Research Service.

Paul Rundquist, Specialist in American National Government, "The Congressional Record"

Judy Schneider, Specialist in American Government, "Committee System and Procedures"

*Indicates former Congressional Fellow.

\section{PS Index of Authored Articles}

VOLUME XXI, NO. 1 (MARCH)

THROUGH NO. 4 (DECEMBER) 1989

Alphabetical Index by Author

Andres, Gary J. and Janice A. Beecher. Applied Political Science: Bridging the Gap or a Bridge Too Far? September (3), p. 636.

Beach, Walter. 1988 Manning Dauer Award to Evron M. Kirkpatrick. March (1), p. 79.

Bosso, Christopher J. Congressional and Presidential Scholars: Some Basic Traits. December (4), p. 839.

Bowen, Gordon L. Presidential Action and Public Opinion About U.S.Nicaraguan Policy. December (4), p. 793.

Brunk, Gregory G. Social Science Journals: A Review of Research Sources and Publishing Opportunities for Political Scientists. September (3), p. 617.

Bunce, Valerie. Eastern Europe: Is the Party Over? June (2), p. 233.

Dawson, Paul. Reviews of Undergraduate Departments: An External Reviewer's Perspective. March (1), p. 63.

de Montricher, Nicole. French Political Science. March (1), p. 146.

De Vries, Walter. American Campaign Consulting: Trends and Concerns. March (1), p. 21.

Dye, Thomas R. and Harmon Zeigler. Socialism and Militarism. December (4), p. 800.

Eckstein, Harry. A Comment on Positive Theory. March (1), p. 77.

Elkin, Stephen L. China Witness. September (3), p. 579.

Erikson, Robert. Why the Democrats Lose Presidential Elections. March (1), p. 30 .

Euchner, Jonathan P. and Malcolm E. Jewell. A Survey of Teaching by Graduate Students. March (1), p. 73.

Frantzich, Stephen. It's Time for Scholars to be Heard. March (1), p. 78.

Freeman, Jo. Feminist Activities at the 1988 Republican Convention. March (1), p. 39.

Galey, Margaret E. Gender Roles and UN Reform. December (4), p. 813.

Garcia, F. Chris, John A. Garcia, Angelo Falcon and Rodolfo O. de la Garza. Studying Latino Politics: The Development of the Latino National Political Survey. December (4), p. 848.

Giles, Micheal W., David Patterson and Francie Mizell. Discretion in Editorial Decision-making. March (1), p. 58.

Giles, Micheal, Randall Strahan and Rick Doner. Dining in Atlanta. June (2), p. 283. 